\title{
ANALISIS FILOGENETIK MANGGA (MANGIFERA SPP.) BERDASARKAN GEN 5,8S RRNA
}

\section{(Analysis of Philogenetic Manggo (Mangifera spp.) Based On RRNA 5,8S Gene)}

Olivia Anafarida dan Badruzsaufari

Program Studi Biologi, FMIPA Universitas Lambung Mangkurat,

Jalan A. Yani Km.36, Banjarbaru, Indonesia

Email: Olivia.anafarida@gmail.com

Article Submitted : 29-5-2020

Article Accepted : 03-6-2020

\begin{abstract}
Phylogenetic analysis of mangoes species using the nucleotide sequences of 5.8S rRNA genes aimed to determine the cladistics and evolution of kinship amongst the species of the genus Mangifera to support the conservation and breeding efforts of local endemics of South Kalimantan. The analysis involved 23 nucleotide sequences of the 5.8S rRNA gene obtained from the GeneBank of NCBI which were aligned and trimmed into 655 bp using MEGA X software. The Kimura-2 parameter model and Maximum-Likelihood method used to construct a monophyletic tree of 4 clades. Clade I consists of $M$. torquenda, M. sumatrana, $M$. kemanga, $M$. quadrifida, M. griffithii, M. casturi, M. lalijiwa, M. macrocarpa, M. flava, M. gracilipes, $M$. pentandra and M. caloneura. Clade II consists of $M$. foetida, M. cochinchinensis, M. gedebe, $M$. oblongifolia, $M$. indica, $M$. laurina, $M$. sylvatica, and $M$. zeylanica. Clade III only consists of $M$. andamanica. Clade IV consists of $M$. odorata and $M$. camptosperma. The closest kinship occurred between $M$. odorata and $M$. camptosperma and the farthest kinship was $M$. camptosperma. M. andamanica has the farthest evolutionary distance with the longest branch.
\end{abstract}

Keywords: Phylogenetic, Mangifera, evolution, kinship

\section{PENDAHULUAN}

Mangifera merupakan genus dari mangga-manggaan anggota famili Anacardiaceae, yang memiliki sekitar 49 spesies dengan 8 spesies berstatus belum valid sedangkan 41 spesies lainnya merupakan spesies yang sudah valid. Menurut Luo dkk., (2010) mangga berasal dari India lebih dari 4000 tahun yang lalu dan tersebar di beberapa Negara meliputi India, Malaysia, Srilanka, Filipina, Papua Nugini, China dan Indonesia (Yadav \& Singh, 2017). Genus ini tersebar di wilayah tropis baik dataran tinggi maupun dataran rendah (Kostermans \& Boompard, 1993).
Mangga kasturi (M. casturi), mangga kuweni ( $M$. odorata) dan mangga lalijawa (M. lalijawa) merupakan sebagian kecil spesies mangga yang ada di Indonesia. Genus ini dibagi menjadi 2 subgenus yaitu subgenus Mangifera dan subgenus limus. Subgenus Mangifera diantaranya yaitu $M$. indica, M. camptosperma, $M$. casturi dan $M$. gedebe sedangkan subgenus limus diantaranya yaitu $M$. odorata, $M$. foetida dan $M$. gracilipes (Kostermans \& Bompard, 1993). Menurut Rhodes \& Maxted (2016) mangga kasturi (M. casturi) yang merupakan mangga endemik 
Kalimantan Selatan berdasarkan kategori IUCN Red List masuk dalam kategori Extinc in the wild atau sudah tidak ditemukan lagi di habitat liarnya dan hanya ditemukan di habitat budidaya. Populasi Mangifera di alam semakin berkurang akibat tingginya deforestasi hutan. Areal hutan semakin berkurang akibat penebangan liar, pengalihan lahan, industrialisasi dan sebagainya (Fitmawati dkk., 2013). Konservasi serta budidaya perlu dilakukan untuk mencegah semakin banyaknya spesies Mangifera yang hilang. Banyak jenis mangga di dunia yang belum diketahui secara pasti hubungan kekerabatannya. Tindakan pertama untuk menentukan strategi konservasi serta cara budidaya yakni dengan mengetahui hubungan evolusi yang direkonstruksi dari spesies Mangifera. Oleh karena itu perlu dilakukan penelitian mengenai kekerabatan antar spesies mangga sehingga keberhasilan dalam pelestariannya dapat dilakukan dengan mudah.

Identifikasi menggunakan data morfologi sulit dilakukan karena membutuhkan waktu yang lebih lama serta musim buah dan bunga yang tidak menentu (Lestari dkk., 2018). Sebaliknya identifikasi menggunakan data molekuler seperti DNA atau protein juga membutuhkan waktu yang lama karena menggunakan laboratorium serta peralatan canggih lainnya. Alternatif lain yang dapat digunakan untuk membuat pohon filogenetik adalah dengan menggunakan data sekunder. Menurut Sugiyono (2010) data sekunder merupakan data yang tidak diperoleh secara langsung yakni melalui internet, jurnal, buku dan sebagainya. Data sekunder yang digunakan berupa DNA atau protein yang berasal dari website NCBI. Dengan mengumpulkan data yang sergam maka data yang dihasilkan pun akan lebih akurat dan efektif dibandingkan penelitian secara langsung.

Analisis kekerabatan perlu dilakukan untuk mengetahui kekerabatan antar spesies dari genus Mangifera. Hubungan evolusi antar spesies dapat digambarkan melalui analisis filogenetika menggunakan data molekuler berupa DNA atau protein (Dharmayanti, 2011). Data yang digunakan yaitu sekuens nukloeotida 23 spesies mangga yang didapatkan dari website NCBI yakni gen 5,8S rRNA yang merupakan bagian penting ribosom eukariotik yang disalin oleh RNA polimerase I (Sequence Ontology, 2020) .

Metode yang umum digunakan dalam analisis kekerabatan adalah filogenetika yang dapat digunakan untuk menafsirkan kekerabatan antar spesies dengan rekonstruksi filogenetik (Hidayat \& Pancoro, 2008). Pohon filogenetik merupakan susunan yang dapat menggambarkan data yang berkerabat dalam bentuk pohon bercabang (Lubis, 2014). Berdasarkan garis evolusi studi filogenetik dengan penanda molekuler dapat menganalisis hubungan genetik antar kelompok organisme (Hidayat \& Pancoro, 2008). Model Kimura-2 dipilih dalam pembuatan filogenetik untuk mengetahui kesamaan antar sekuens serta memiliki kelebihan cepat dan mudah untuk menganalisis sekelompok sekuens (Bhambri \& Gupta, 2012). Analisis filogenetik ini bertujuan untuk mengetahui kladistika serta evolusi kekerabatan antar spesies dalam genus Mangifera sehingga dapat memudahkan dalam upaya konservasi serta pemuliaan mangga-manggaan.

\section{METODE PENELITIAN}

Penelitian ini menggunakan data sekunder berupa sekuens nukleotida genus Mangifera 5,8S rRNA yang berasal dari GeneBank melalui website NCBI (National Center for Biology Information). Spesies out group yang dipilih adalah Oryza sativa cultivar Tongil. Sekuens dalam file format teks dipangkas (trimmed) mengikuti panjang sekuens terpendek yaitu $655 \mathrm{bp}$. Selanjutnya file tesebut dikonversi menjadi format Mega menggunakan software MEGA X (Tamura dkk., 2007). 


\section{Analisis}

Sekuens nukleotida dianalisis pensejajaran sekuens (edit/alignment build) dengan Clustal-W dengan software MEGA $X$. Sekuens yang memiliki banyak kemiripan dipotong pada ujung 5', ujung 3' atau keduanya. Analisis filogenetika menggunakan metode maxsimum likelihood dengan bootstrap sebanyak 1000 menggunakan model Kimura 2-parameter. Pohon filogenetik yang sudah terbentuk terbagi menjadi 2 jenis yakni original dan hasil bootstrap.

\section{HASIL DAN PEMBAHASAN}

Dua puluh tiga sekuens nukleotida gen 5,8S rRNA dari spesies yang termasuk dalam genus Mangifera dan 1 spesies out group dari genus Oryza dipilih untuk analisis disajikan pada Tabel 1. Rekonstruksi pohon filogenetik menggunakan model Kimura-2 didapatkan 2 jenis pohon filogenetik yakni bootsrap tree (Gambar 1) dan original tree (Gambar 2).

Tabel 1. Daftar spesies yang diperoleh dari website NCBI (National Center for Biology Information)

\begin{tabular}{cllc}
\hline No. & \multicolumn{1}{c}{ Spesies } & Subgenus & No. Aksesi GenBank \\
\hline 1. & Mangifera kemanga & Limus & MF990368.1 \\
2. & Mangifera quadrifida & Mangifera & MF678511.1 \\
3. & Mangifera torquenda & Mangifera & MF990365.1 \\
4. & Mangifera sumatrana & Mangifera & KX347961.1 \\
5. & Mangifera griffithii & Mangifera & AB071685.1 \\
6. & Mangifera casturi & Mangifera & MF678493.1 \\
7. & Mangifera lalijiwa & Mangifera & MF678504.1 \\
8. & Mangifera oblongifolia & Mangifera & AB071682.1 \\
9. & Mangifera gedebe & Mangifera & AB071681.1 \\
10. & Mangifera foetida & Limus & AB071680.1 \\
11. & Mangifera cochinchinensis & Mangifera & AB071677.1 \\
12. & Mangifera macrocarpa & Limus & AB071688.1 \\
13. & Mangifera gracilipes & Mangifera & AB071686.1 \\
14. & Mangifera pentandra & Mangifera & AB071684.1 \\
15. & Mangifera flava & Mangifera & AB071679.1 \\
16. & Mangifera caloneura & Mangifera & AB071678.1 \\
17. & Mangifera laurina & Mangifera & AB598044.1 \\
18. & Mangifera odorata & Limus & LN552225.1 \\
19. & Mangifera indica & AB598046.1 \\
20. & Mangifera andamanica & Mangifera & AJ890470.1 \\
21. & Mangifera sylvatica & Mangifera & AJ890469.1 \\
22. & Mangifera zeylanica & Mangifera & KM08043.1 \\
23. & Mangifera camptosperma & Mangifera & \\
24. & Oryza sativa cultivar Tongil & Mangifera &
\end{tabular}

Topologi pohon filogenetik yang dihasilkan bersifat monofiletik yang berarti bahwa kelompok tersebut memiliki satu leluhur yang mewariskan sifat genetik, morfologi serta biokimia pada semua keturunannya. Hal tersebut membuat anggota monofiletik berkerabat sangat dekat antara satu dengan yang lain (Hidayat \& Pancoro, 2008). Pernyataan tersebut sesuai dengan pohon filogenetik yang terbentuk, karena seluruh anggota dalam pohon filogenetik (kecuali out group) berasal dari 
satu genus yang sama yakni genus Mangifera.

Kladogram dengan metode maximum likelihood membentuk 4 kelompok in group dan 1 out group. Kelompok in group terbagi dalam dua klad besar yakni klad I dan klad II serta dua klad kecil yakni klad III dan klad IV. Klad I terdiri dari 12 spesies yakni $M$. torquenda, $M$. sumatrana, $M$. kemanga, $M$. quadrifida, $M$. griffithii, $M$. casturi, $M$. lalijiwa, $M$. macrocarpa, $M$. flava, $M$. gracilipes, $M$. pentandra dan $M$. caloneura. Jenis-jenis tersebut disatukan oleh banyaknya urutan sekuens yang mempunyai kemiripan yang sama. Karakter morfologi yang memisahkan jenis tersebut dari klad yang lain adalah permukaan daun glabrous serta warna kulit buah yang unik pada beberapa spesies. M. casturi, M. kemanga, $M$. torquenda, $M$. griffithii, dan $M$. quadrifida meemiliki warna buah yang gelap (hitam keunguan dan coklat) saat matang, sedangkan spesies lainnya memiliki warna kulit buah kekuningan dan berbintik-bintik (Kostermans \& Boompard, 1993).

Klad IV terdiri dari 2 spesies yakni $M$. odorata dan $M$. camptosperma. Kedua spesies tersebut disatukan oleh banyaknya persamaan karakter sekuens yang dimiliki sehingga mengelompok dalam satu klad. Karakter morfologi daun oblong-lanceolate, bunga berwarna putih kemerahan serta daging buah yang hijau saat matang (Kostermans \& Boompard, 1993).

Kladogram pada Gambar 1 menunjukan bahwa subgenus Mangifera dan Limus terletak pada cabang yang berbeda. Lestari dkk., (2018) menegaskan, topologi pohon filogenetik yang dihasilkan melalui proses analisis terbagi menjadi beberapa klad yang tersusun dari subgenus yang sama. Pohon filogenetik yang dihasilkan berbeda dengan pernyataan tersebut. Subgenus Mangifera dan subgenus Limus tidak membentuk kelompok khusus melainkan tercampur satu sama lain. Hal tersebut disebabkan oleh penggunaan sekuens yang lebih spesifik dibandingkan karakter morfologi. Menurut
Klad II terdiri dari 8 spesies yakni $M$. foetida, M. cochinchinensis, M. gedebe, M. oblongifolia, $M$. indica, $M$. laurina, $M$. sylvatica dan $M$. zeylanica. Banyaknya kemiripan antar sekuens yang dimiliki ke enam spesies tersebut membuatnya masuk dalam klad yang sama. Jenis-jenis tersebut memiliki karakter morfologi yang mirip antara satu dengan yang lain, diantaranya yaitususunan daun tersebar, bentuk daun oblong, struktur bunga dengan 5 helai sepal dan petal, bentuk buah seperti paruh serta permukaan buah yang mengkilap (Kostermans \& Boompard, 1993).

Klad III terdiri dari satu spesies yaitu $M$. andamanica. Spesies tersebut memiliki urutan sekuens yang jauh berbeda dengan anggota genus Mangifera yang lain sehingga membentuk kelompok tersendiri. Karakter morfologi spesies ini yaitu memiliki daun spathulate hingga oblong, bunga putih serta kelopak dan mahkota 4 , buah elips, tidak berparuh (tidak meruncing) (Kostermans \& Boompard, 1993).

Kostermans \& Boompard (1993), Subgenus tersebut dibagi berdasarkan karakter morfologi bunga yaitu struktur pembungaan, bentuk helai mahkota dan ukuran helai mahkota, jumlah benang sari fertil, tipe perbungaan dan bentuk disc pada bunga (Swita $d k k ., 2013$ ). Berbeda cara pendekatan antara karakter morfologi dan karakter molekuler membuat kedua subgenus tersebut terpisah.

Berdasarkan letak cabang dan nilai bootstrap, kekerabatan terdekat dimiliki oleh $M$. odorata dan $M$. camptosperma dengan nilai bootstrap 100. Menurut Rosidiani $d k k$., (2013) nilai bootstrap dengan rentang 70100 menunjukan peluang terjadinya perubahan pada klad kecil sedangkan nilai bootstrap kurang dari 70 menunjukan peluang perubahan susunan klad besar. Besarnya nilai bootstrap serta letak garis yang sejajar membuat keduanya berkerabat dekat. 


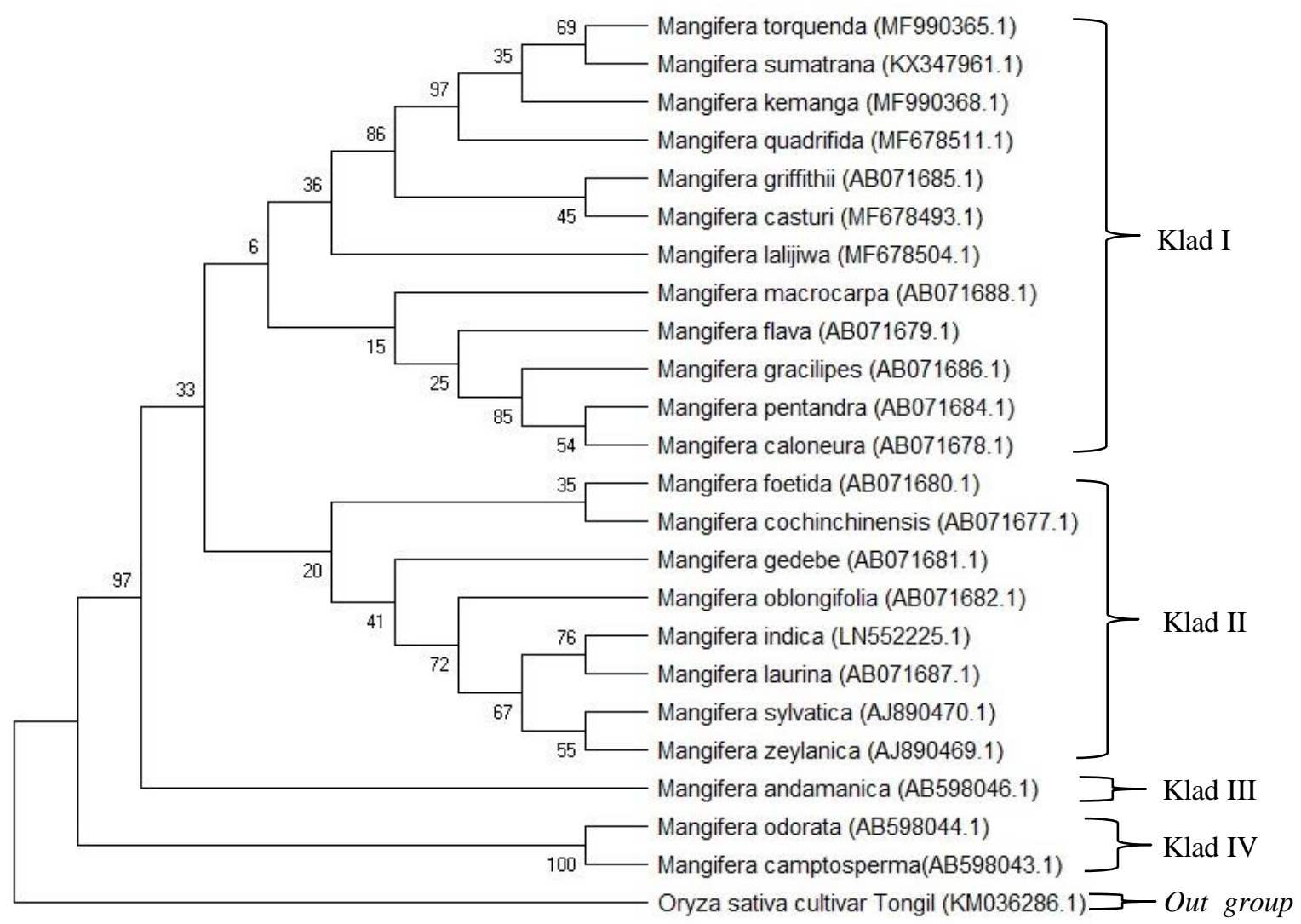

Gambar 1. Pohon filogenetik bootstrap Mangifera dengan 23 spesies in group dan 1 spesies out group berdasarkan urutan 5,8S rRNA. Direkonstruksi menggunakan software MEGA X. Nilai-nilai bootstrap (1000 ulangan) untuk setiap node ditampilkan di pangkal cabang

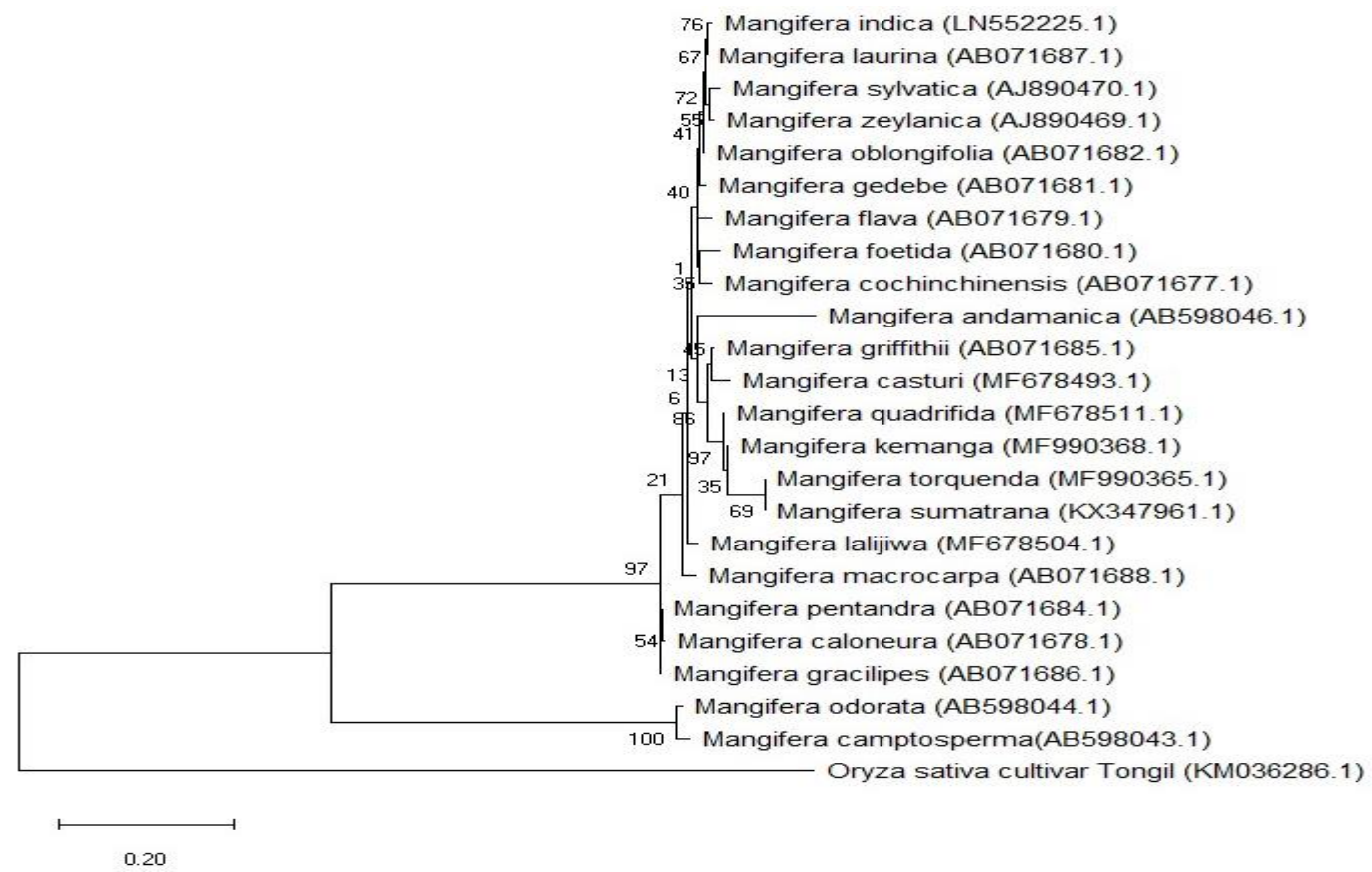

Gambar 2. Pohon filogenetik original Mangifera dengan 23 spesies in group dan 1 spesies out group berdasarkan urutan 5,8S rRNA. 
Analisis metode maximum likelihood menggunakan model Kimura-2 merekonstruksi kekerabatan antar spesies berdasarkan panjang garis cabang. Panjang garis yang berbeda menunjukan tingkat evolusi masing-masing spesies (Fitmawati $d k k l$. , 2013). Garis yang semakin panjang menunjukan jarak evolusi semakin jauh sedangkan garis yang lebih pendek menunjukan dekatnya jarak evolusi suatu spesies. Berdasarkan Gambar 2, garis terpanjang dimiliki oleh $M$. andamanica anggota klad III dengan cabang terpanjang. Hal tersebut menunjukan bahwa spesies ini mempunyai sejarah evolusi yang panjang sehingga dianggap lebih primitif (Fitmawati $d k k$., 2018). Cabang-cabang lainnyayang lebih pendek menunjukan bahwa spesiesspesies lain memiliki evolusi pendek dengan sifat lebih maju, sehingga dianggap sebagai keturunan dari nenek moyangnya. Dengan demikian $M$. andamanica merupakan spesies yang memiliki umur molekuler terdahulu sebagai nenek moyang dari Mangifera lainnya.

Kladogram memberi petunjuk bahwa 23 jenis mangga kelompok in group mengelompok dalam masing-masing klad berdasarkan kemiripan sekuens nukleotida serta kemiripan pada beberapa karakter morfologi yang digunakan sebagai pendukung. Persamaan serta perbedaan karakter yang dimiliki antar spesies tersebut digunakan untuk mengetahui hubungan

\section{DAFTAR PUSTAKA}

Bhambri, P., \& Gupta, O. P. (2012). Development of phylogenetic tree based on Kimura's Method. Proceedings of 2012 2nd IEEE International Conference on Parallel, Distributed and Grid Computing, PDGC 2012, 1-3. https://doi.org/10.1109/PDGC.2012.64 49910

Dharmayanti, N. L. P. I. (2011). Filogenetika Molekuler: Metode kekerabatannya. Tingkat evolusi masingmasing spesies dapat dilihat dari panjang pendeknya cabang kladogram. Semakin panjang cabang menunjukan bahwa spesies tersebut adalah nenek moyang dengan sifat kuno sedangkan semakin pendek cabang menunjukan bahwa spesies tersebut merupakan keturunan dari spesies dengan nilai cabang panjang.

\section{KESIMPULAN}

Analisis filogenetik dari 23 spesies Mangifera berdasarkan sekuens 5,8S rRNA dapat disimpulkan bahwa kladogram yang dihasilkan menggunakan metode maximum likelihood bersifat monofiletik yang terbagi dalam 4 klad. Klad I terdiri dari $M$. torquenda, $M$. sumatrana, $M$. kemanga, $M$. quadrifida, $M$. griffithii, $M$. casturi, $M$. lalijiwa, $M$. macrocarpa, $M$. flava, $M$. gracilipes, $M$. pentandra dan $M$. caloneura. Klad II terdiri dari $M$. foetida, $M$. cochinchinensis, M. gedebe, M. oblongifolia, $M$. indica, M. laurina, $M$. sylvatica dan $M$. zeylanica. Klad III hanya terdiri dari $M$. andamanica. Klad IV terdiri $M$. odorata dan M. camptosperma. Berdasarkan letak cabang dan nilai bootstrap kekerabatan terdekat dimiliki oleh $M$. odorata dan $M$. camptosperma. Berdasarkan cabang terpanjang $M$. andamanica bersifat primitif sebagai nenek moyang dari Mangifera lainnya.

Taksonomi Organisme. Wartazoa, 21(30), 1-10.

Fitmawati, A., Suwita, N., \& Sofiyanti, H. (2013). Eksplorasi dan Karakterisasi Keanekaragaman Plasma Nutfah Mangga (Mangifera) di Sumatera Tengah. Prosiding Semirata FMIPA Universitas Lampung, 307-312.

Fitmawati, F., Riau, U., \& Juliantari, E. (2018). Phylogenetic Study of 
Mangifera Central Sumatra Based on rbcl Sequences Phylogenetic Study of Mangifera Central Sumatra Based on rbcl Sequences. (February).

Hidayat, T. \& Pancoro. A. (2008). Kajian Filogenetika Molekuler dan Peranannya dalam Menyediakan Informasi Dasar untuk Meningkatkan Kualitas Sumber Genetik Anggrek Topik. AgroBiogen, 4(1), 35-40.

Kostermans, A. J. G. H. \& Jean. M. B. (1993). The Mangoes. London: Academic Press Limited.

Lestari, D. A., Azrianingsih, R., \& Hendrian, H. (2018). Filogenetik Jenisjenis Annonaceae dari Jawa Timur Koleksi Kebun Raya Purwodadi Berdasarkan Coding dan Non-coding sekuen DNA. Journal of Tropical Biodiversity and Biotechnology, 3(1), 1. https://doi.org/10.22146/jtbb.28308

Lubis, K. (2014). Cara Pembuatan Pohon Filogeni. Pengabdian Kepada Masyarakat, 20(XX), 66-69.

Luo, C., He, X. H., Chen, H., Ou, S. J., \& Gao, M. P. (2010). Analysis of diversity and relationships among mango cultivars using Start Codon Targeted (SCoT) markers. Biochemical Systematics and Ecology, 38(6), 11761184.

https://doi.org/10.1016/j.bse.2010.11.0 04

Rhodes, L. \& Maxted, N. (2016). Mangifera casturi. The IUCN Red List of Threatened Species 2016: e.T32059A61526819.
http://dx.doi.org/10.2305/IUCN.UK.20 16-3.RLTS.T32059A61526819.en

Rosidiani, E. P., Arumingtyas, E. L., \& Azrianingsih, R. (2013). Analisis Variasi Genetik Amorphophallus muelleri Blume dari Berbagai Populasi di Jawa Timur Berdasarkan Sekuen Intron trnL. Floribunda, 4(6), 129-137.

Sequence Ontology. (2013). Categor:SO:04375 ! Rrna 5,8S. http ://www. sequenceontology. org/so_wiki/index. php/Category : SO:0000375_!_rRNA_5_8S. Diakses 5 April 2020

Sugiyono. (2010). Metode Penelitian Kuantitatif, kualitatif dan $R$ \& $D$. Bandung: Alfabeta.

Swita, A. F. \& M. (2013). Analisis Hubungan Kekerabatan Beberapa Jenis Mangga (Mangifera) Berdasarkan Karakter Morfologi dan Flouresensi Klorofil. Jurnal Produksi Tanaman.

Swita, A., \& Sofyanti, N. (2013). Analisis Kekerabatan Morfologi Mangifera Dari Sumatera Tengah. Floribunda, 4(7), 169-174.

Tamura K, J. Dudley, M. Nei \& S. Kumar. 2007. MEGA4: Molecular Evolutionary Genetics Analysis (MEGA) software version 4.0. Molecular Biology and Evolution 24:1596-1599.

Yadav D \& S. P., \& Singh. (2017). Mango: History origin and distribution. Journal of Pharmacognosy and Phytochemistry, 6(6), 1257-1262. 